\title{
Correlation of Nitric Oxide (NO) Sputum Level and Lung Physiology of Indoor Parking Attendant
}

\author{
Tati Sudiarti $^{1}$, Winariani ${ }^{1}$ \\ ${ }^{1}$ Department of Pulmonology and Respiration, Faculty of Medicine, Universitas Airlangga, Dr. Soetomo General \\ Hospital, Surabaya 60285, Indonesia
}

\begin{abstract}
Background: Air contamination inside the building causes respiratory inflammation and increases NO sputum levels that cause changes in parking staffs' lung physiology.

Objective: To analyze the correlation between NO sputum level and lung physiology of indoor parking attendant.

Method: This research was conducted at the Toserba oceans in Tasikmalaya West Java, Indonesia with a sample of 40 people. Twenty indoor parking attendants as an exposed group and 20 administrative officers as a control group. Sputum NO and lung physiology were examined in both groups. The measurement of NO sputum level was using Griess method and lung physiology was by spirometry of brand of Fukuda.

Results: The mean of NO sputum level in the exposed group was $4689.75 \pm 6778.452$ and in the control group was $485.25 \pm 307$, the mean of NO level was obtained a significant difference between exposed group and control group $(\mathrm{p}=0.009)$. The results of lung physiology examination in both exposure and control group from $\%$ FEV1, \% FEV1 / FVC showed significant differences $(p<0.05)$. While $\%$ FVC did not show a significant difference ( $p>0.05)$. The result of the Pearson correlation test showed a strong positive correlation between NO sputum level and lung physiology of indoor parking attendant $(r=0.461$ with $\mathrm{p}$ $<0.041)$.
\end{abstract}

Conclusion: There was a correlation between NO sputum level and lung physiology of indoor parking attendant.

Keywords: Indoor parking attendant, NO level, Lung function, Vehicle emission level

\section{Introduction}

The World Health Organization (WHO) estimates that urban air pollution contributes about 800,000 deaths each year and disability of around 4.6 million every year worldwide. The burden is uneven that about two-thirds of the deaths/years occur in developing countries in Asia $^{1}$.

\section{Corresponding Author:}

\section{Winariani}

Department of Pulmonology and Respiration, Faculty

of Medicine, Universitas Airlangga, Dr. Soetomo

General Hospital, Surabaya 60285, Indonesia

Email:winarianiwina@gmail.com
In the 1990s, many epidemiological studies reported the adverse effects of air pollution on health 2. Environmental factors play an important role in the development of respiratory diseases. The presence of various particles and gases from vehicle emissions such as carbon dioxide, carbon monoxide, sulfur, benzene, lead, nitrogen dioxide and black smoke have a role in the pathogenesis of the respiratory disease. Toxic chemicals and non-combustible gases resulting from motor vehicle emissions might cause respiratory tract irritation. In the long run, exposure to pollutants possibility leads to the occurrence of diseases such as asthma and bronchitis as well as the occurrence of lung physiological changes ${ }^{3}$.

The results of research in several cities (Jakarta, Bandung, Semarang, and Surabaya) showed that motor 
vehicles were the main source of air pollution. The problem of air pollution due to vehicle emissions has reached a worrying point, especially in big cities. Motor traffic is quite dense that could affect air quality, traffic density not only occur on the highway but also can occur in the parking lot due to increased motor vehicle users which ultimately affect the air quality in the parking lot 4.

Based on several studies, air pollution might affect respiratory distress through reactive oxygen species (ROS) pathways. ROS could lead to respiratory tract cell to damage by inducing apoptosis (cell programmed cell death) and cell necrosis that will enhance the proinflammatory cytokine mediator and some chemokines including tumor necrosis factor alpha (TNF- $\alpha$ ) and interleukin-8 (IL-8). This process could ultimately lead to decreased lung physiology function 5 , and plays an important role in various lung diseases, including asthma and chronic obstructive pulmonary disease (COPD) ${ }^{6}$.

Nitric Oxide (NO) is a short-lived intercellular material that has been shown to be important in many biological functions including neurotransmission, defense systems, immune function, and inflammation. Pathophysiology of lung disease associated with NO. Previous research has shown that measurement of NO expiratory air concentration can represent non-invasive measurements of inflammation in the airways. In particular, NO expiratory air has been shown to be a marker associated with chronic cough symptoms, COPD, and asthma. Several studies have examined the effects of air pollution on subclinical inflammatory markers such as NO. In a longitudinal study in elementary school students aged 8-13 years found that exposure to black smoke, nitrogen dioxide (NO2), and particles smaller than $10 \mathrm{~mm}$ (PM10) was associated with an increase in NO expiratory air. Pollutants are also associated with decreased peak expiratory currents and increased inflammatory markers in nasal lavage samples ${ }^{6}$.

Based on some evidence that mention of NO plays an important role in respiratory tract physiology and become an indicator of inflammation. Previous research examined levels of NO sputum of asthma patients whose results were higher compared with controls ${ }^{7}$. Normal NO value of sputum was $502 \mu \mathrm{m} / \mathrm{L}$ with standard deviation $414^{8}$. The half-life of NO in the tissue is very short (about 1-5 seconds), the direct NO test is not easy to do so the examination was performed indirectly using
Griess reaction ${ }^{9}$.

The parking attendant, especially those working in closed rooms (Indoor) that are not equipped or not functioning air ducts so the vehicle exhaust gas will accumulate in the parking space, consequently affect the respiratory system. In research conducted by Almaditya to the parking attendant, the obstruction was obtained $80 \%$ and restriction $85 \%$. Based on the above background, this research will be examined about the correlation of NO sputum level with lung physique of an indoor parking attendant.

\section{Method}

The subjects of this research were indoor parking attendants and the Tasikmalaya Ocean General Store administration officers who fulfill the inclusion and exclusion criteria. The inclusion criteria consisted of ages 18 to 55 years, have worked at least 1 year, able and cooperative undergo the procedure of induction of sputum and examination of lung physiology. Exclusion criteria were subjects with a history of bronchial asthma, heart disease, diabetes mellitus, rheumatoid arthritis, pulmonary tuberculosis, lung tumors, Chronic Obstructive Pulmonary Disease, and pneumonia. Allergic rhinitis. Free from drugs that affect the levels of NO (antioxidant, vitamin C). Subjects who are willing to participate by fill out the informed consent sheet and sign it.

This research was conducted in the parking area of the indigenous seashores of Tasikmalaya oceans using cross-sectional design. The data were collected using questionnaires and physical examination, subject demographic factors (sex, age, height, weight, duration of work), thoracic photos, vehicle emission measurements, NO-induced sputum and lung physiology. Sputum was obtained by inhalation induction using $2 \mathrm{ml}$ of $\mathrm{NaCl}$ solution $2 \mathrm{ml}$ with ultrasonic nebulizer device until the solution was exhausted then subjects were told to cough sputum on the sterile pot which had been prepared. Sputum NO concentration using Sputum was centrifuged for 15 minutes at a rate of $3000 \mathrm{~g}$, cell culture supernates obtained were included in an eppendorf tube and stored at $-20^{0} \mathrm{C}$.

The pulmonary physiological examination was performed at the agreed time with a portable spirometer device of Fukuda Sangyo ST 75 brand. The examination was performed three times and the highest result was taken as the data to be analyzed. The values recorded are 
FVC, FEV1 and FEV1 / FVC ratios. The measurement of vehicle emissions was performed by Air Quality Measurement System (AQMS). Measurements were made for at least 1 hour then recorded in report form. Automated monitoring equipment (AQMS), this equipment continuously monitor ambient air quality and produce the data that could set as needed. Parameters measured by this tool were carbon monoxide (CO), O3, PM10, NO2, and Sulfur dioxide (SO2).

The collected data were processed using SPSS (SPSS, Inc., Chicago, IL) with $\mathrm{p}<0.05$. To analyze the correlation of NO sputum level with lung physiology used correlation statistic functioned to describe the relationship of NO content-induced sputum with indoor lung parking attendant physique. The test used was Pearson test and Spearman test.

Table 1. Measurement data of research subjects

\section{Results \\ Characteristics of Respondents}

Based on the length of the working period less than or equal to 10 years dominated by exposure group was $90.00 \%$ and in the control group was $65.00 \%$. Based on smoking status in this study was dominated by smoking habit. In the exposure group, it consisted of 16 people smoking and in the control group consisted of 12 people smoking. Based on the abnormalities of lung physiology in this study was obtained more abnormal obstruction in the exposure group by $50 \%$. While in the control group was $10 \%$. Restriction and mixed abnormalities were not obtained in both groups of both exposed and control groups. Viewed from the abnormalities of lung physiology, there was a significant difference between the exposed group and the control group $(\mathrm{p}=0.005)$ (Table 1).

\begin{tabular}{|c|c|c|}
\hline Characteristics & Exposed group (\%) or Mean \pm SD & Control (\%) or Mean \pm SD \\
\hline $\begin{array}{l}\text { Sex } \\
\text { Male } \\
\text { Female }\end{array}$ & $\begin{array}{l}20(100.00) \\
0(0.00)\end{array}$ & $\begin{array}{l}17(85.00) \\
3(15.00)\end{array}$ \\
\hline $\begin{array}{l}\text { Job durations } \\
\leq 10 \text { year } \\
>10 \text { year }\end{array}$ & $\begin{array}{l}18(90.00) \\
2(10.00)\end{array}$ & $\begin{array}{l}13(65.00) \\
7(35.00)\end{array}$ \\
\hline $\begin{array}{l}\text { Habit } \\
\text { Smoking } \\
\text { Un-smoking }\end{array}$ & $\begin{array}{l}16(80.00) \\
4(20.00)\end{array}$ & $\begin{array}{l}12(60.00) \\
8(40.00)\end{array}$ \\
\hline $\begin{array}{l}\text { Lung physiology abnormalities } \\
\text { Normal } \\
\text { Obstruction }\end{array}$ & $\begin{array}{l}10(50.00) \\
10(50.00)\end{array}$ & $\begin{array}{l}18(90.00) \\
2(10.00)\end{array}$ \\
\hline Age & $39.50 \pm 12.20$ & $33.95 \pm 9.25$ \\
\hline Years of service & $6.40 \pm 2.43$ & $9.95 \pm 6.97$ \\
\hline NO Level & $4689.75 \pm 6778.45$ & $485.25 \pm 307.08$ \\
\hline
\end{tabular}

In the exposure group, it was obtained the youngest age was 21 years and the oldest was 55 years, while the control group obtained the youngest age at the age of 20 years and the oldest age at the age of 53 years. Judging from age there was no significant difference between the exposed group and the control group $(p=0.113)$. In the exposed group, the shortest working period was 3 years and the longest working period was 11 years, while in the control group, the shortest working period was the age of 2 years and the longest working period 
of 28 years. The mean of the subjects was obtained a significant difference between the exposed group and the control group $(\mathrm{p}=0.038$; Table 1$)$.

\section{Comparison of Lung Physiology}

The comparison of \% FVC based on the smoking status of the exposed group was The mean $\mathrm{FVC} \%$ of the non-smoking group was higher than the smoking group, but the t-test at \% FVC has obtained a p-value of 0.262 .
The comparison of $\%$ FEV 1 based on the smoking status of the exposed group. The mean of \% FEV1 group that was not smoking is higher than a smoking group but, the T-test at $\%$ FEV1 yielded $p$-value $=0.454$. Comparison of $\% \mathrm{FEV} 1 / \mathrm{FVC}$ based on the smoking status of the exposed group. The mean FEV1/FVC\% of the nonsmoking group was higher than the smoking group, but, the $\mathrm{t}$-test at \% FEV1/FVC yielded a p-value of 0.944 (Table 2).

Table 2. Comparison of lung physiology based on smoking and group status

\begin{tabular}{|l|l|l|l|l|l|l|}
\hline \multirow{2}{*}{} & \multicolumn{2}{|l|}{ Groups } & \multirow{2}{*}{$\mathbf{p}$} & \multicolumn{2}{l|}{ Smoking status } \\
\cline { 2 - 6 } & Exposed & Control & & Non-smoking & Smoking \\
\hline$\%$ FVC & $121.40 \pm 13.17$ & $129.30 \pm 11.96$ & 0.054 & $126.50 \pm 7.93$ & $120.13 \pm 14.09$ & 0.262 \\
\hline$\%$ FEV1 & $106.45 \pm 15.99$ & $118.35 \pm 12.84$ & 0.013 & $111.75 \pm 14.17$ & $105.13 \pm 16.57$ & 0.454 \\
\hline$\%$ FEV1/FVC & $75.15 \pm 5.43$ & $83.45 \pm 6.25$ & 0.000 & $75.25 \pm 1.70$ & $75.13 \pm 6.06$ & 0.944 \\
\hline
\end{tabular}

\section{Discussion}

The average age of subjects was 37.56 years, but no significant correlation was obtained between age and lung function impairment ${ }^{10}$. Based on smoking status dominated by smoking habits. In the exposure group, it consisted of 16 people smoking and 4 people did not smoke, while in the control group consisted of 12 people smoking and 8 people did not smoke. This was in accordance with previous research consisting of 57 people who smoke and 46 people who do not smoke ${ }^{10}$.

There were abnormal lung abnormalities in the exposure group by $50 \%$ and in the control group by $10 \%$. The results of previous research have obtained the decreased vital capacity of lung parking attendant in closed parking with $r=0.51811$. This study was inconsistent with previous research that only obtained $7.9 \%$ of the subjects lung abnormalities and the rest of normal lung physiology 10. Based on the smoking status in this study, more obstruction abnormalities were obtained in the exposed group (50\%). While restriction and mixed abnormalities were unfound in both study and exposure groups 12 .

The results of this study according to Regulation of Minister of Manpower and Transmigration No.Per.13 / MEN / X / 2011 About Threshold Value Physical and Chemical factors in the workplace and the public health guidelines of the city of Illinois on indoor air quality parameters that do not meet the required quality standards are high levels of Sulfur Dioxide (SO2) by $0.68 \mathrm{mg} / \mathrm{Nm}^{3}$ and PM100.05 $\mu \mathrm{g} / \mathrm{Nm}^{3}$ in the indoor parking lot ${ }^{13}$. The result of measurement of vehicle emission level in the indoor parking lot in this study above the air quality standard. Sputum NO concentration can be used as a marker of inflammatory processes in the airways such as asthma ${ }^{12}$. Inflammatory processes can also be caused by pollutants such as vehicle emissions $\left(\mathrm{CO}, \mathrm{SO}_{2}, \mathrm{NO}_{2}, \mathrm{O}_{3}\right.$, $\mathrm{PM}_{10}$ ) being inhaled ${ }^{13}$.

There was a decrease in both FEV1 in case group $(3.1 \mathrm{~L} / \mathrm{sec})$ and FVC in case group $(2.7 \mathrm{~L} / \mathrm{sec})$ than the control group $(3.2 \mathrm{~L} / \mathrm{sec}){ }^{14}$. The changes in FEV1 and FVC were not related to prolonged exposure to pollutants from vehicles after they were correlated with age, height, and level of cigarette consumption ${ }^{15}$.

Currently, there no research that has been done to find the correlation between NO sputum and lung physiology of indoor parking attendant. In this study obtained NO sputum indoor parking officer significantly higher level than administrative officers. The result of ratio measurement (\% FEV1/FVC) of indoor parking officer significantly lower than the administrative officer. We obtain $50 \%$ obstruction in indoor parking attendant and $10 \%$ in administration officer. This indicates that the higher the NO sputum level, the lower the ratio (\% FEV1/ 
FVC). The results were in accordance with the results of measurements of vehicle emission levels (SO2) of 0.68 $\mathrm{mg} / \mathrm{Nm}^{3}$ and PM10 $0.05 \mu \mathrm{g} / \mathrm{Nm}^{3}$ in indoor parking above the quality standard causing irritation and inflammation of the respiratory tract, resulting in increased levels of NO sputum. Airway inflammation results in edema of the respiratory tract resulting in impaired pulmonary physiological disorders in the indoor parking attendant. Sputum NO level with APE value (Flow Peak Expiration) showed a decreasing trend so that the decrease of sputum NO concentration followed by an increase of APE value 16. This means that the higher the NO sputum level, the lower the value of APE. in Osaka Japan, where there was a strong negative correlation between NO sputum level and airway obstruction (FEV1/FVC ratio) with $\mathrm{r}=$ -0.62 and $\mathrm{p}<0.001^{17}$.

The obstacle of this study was the time required to examine all research subjects. The check should take at least 1 hour for each sample. In addition, data collection conducted on working hours of research subjects resulted in each research subject must alternately be served on the field when his colleagues underwent examination in this study. These barriers complicate the process of collecting research data, but the efforts undertaken to deal with it considered able to overcome the problem so that the data collection process can run well.

\section{Conclusion}

There was a correlation between NO sputum level and lung physique of indoor parking officer in Tasikmalaya oceanfront of West Java Province.

Conflict of Interest: The author reports no conflict of interest of this work.

Source of Funding: This study is done with individual funding.

Ethical Clearence: The research process involves participants in the survey using a questionnaire that was accordant with the ethical research principle based on the regulation of research ethic committee. The present study was carried out in accordance with the research principles. This study implemented the basic principle ethics of respect, beneficence, non-maleficence, and justice.

\section{References}

1. Nafstad P. [Health effects of outdoor air pollution]. Tidsskrift for den Norske laegeforening : tidsskrift for praktisk medicin, ny raekke. 2004;124(22):28969.

2. Lagorio S, Forastiere F, Pistelli R, Iavarone I, Michelozzi P, Fano V, et al. Air pollution and lung function among susceptible adult subjects: a panel study. Environmental health : a global access science source. 2006;5:11.

3. Pal P, John RA, Dutta TK, Pal GK. Pulmonary function test in traffic police personnel in Pondicherry. Indian journal of physiology and pharmacology. 2010;54(4):329-36.

4. Yeatts KB, El-Sadig M, Leith D, Kalsbeek W, AlMaskari F, Couper D, et al. Indoor air pollutants and health in the United Arab Emirates. Environmental health perspectives. 2012;120(5):687-94.

5. Singh DP, Gadi R, Mandal TK, Dixit CK, Singh $\mathrm{K}$, Saud $\mathrm{T}$, et al. Study of temporal variation in ambient air quality during Diwali festival in India. Environmental monitoring and assessment. 2010;169(1-4):1-13.

6. Adamkiewicz G, Ebelt S, Syring M, Slater J, Speizer FE, Schwartz J, et al. Association between air pollution exposure and exhaled nitric oxide in an elderly population. Thorax. 2004;59(3):204-9.

7. Dzurik R, Spustova V, Gajdos M. Nitric oxide modulation of metabolic and haemodynamic balance. Bratislavske lekarske listy. 2005;106(89):252-6.

8. Winkler S, El Menyawi I, Linnau KF, Graninger W. Short report: total serum levels of the nitric oxide derivatives nitrite/nitrate during microfilarial clearance in human filarial disease. The American journal of tropical medicine and hygiene. 1998;59(4):523-5.

9. Chataigneau T, Feletou M, Huang PL, Fishman MC, Duhault J, Vanhoutte PM. Acetylcholine-induced relaxation in blood vessels from endothelial nitric oxide synthase knockout mice. British journal of pharmacology. 1999;126(1):219-26.

10. Febrian D. Faal Paru Pada Polisi Lalu Lintas Kota Bekasi Serta Faktor-Faktor Yang Berpengaruh. Depok: Universitas Indonesia; 2013.

11. Albertus N. Korelasi Kadar Partikel Udara Dengan Kapasitas Vital Paru Petugas Parkir Di Universitas Kristen Maranatha Bandung. Bandung: Universitas Kristen Maranatha; 2010.

12. Kumar L, Rajput N, Majumdar S. Nitric oxide metabolites in induced sputum: a noninvasive 
marker of airway inflammation in asthma. Indian pediatrics. 2005;42(4):329-37.

13. Peraturan Pemerintah Republik Indonesia Nomor 41 Tahun 1999 Tentang Pengendalian Pencemaran Udara, (1999).

14. Gupta S, Mittal S, Kumar A, Singh KD. Respiratory effects of air pollutants among nonsmoking traffic policemen of Patiala, India. Lung India : official organ of Indian Chest Society. 2011;28(4):253-7.

15. Tollerud DJ, Weiss ST, Elting E, Speizer FE, Ferris B. The health effects of automobile exhaust. VI. Relationship of respiratory symptoms and pulmonary function in tunnel and turnpike workers. Archives of environmental health. 1983;38(6):33440.

16. Zukri M. Kadar Nitric Oxide (NO) sputum pada penderita asma eksaserbasi. Surabaya: Universitas Airlangga; 2013.

17. Kanazawa H, Shoji S, Yamada M, Fujii T, Kawaguchi T, Kudoh S, et al. Increased levels of nitric oxide derivatives in induced sputum in patients with asthma. The Journal of allergy and clinical immunology. 1997;99(5):624-9. 